\title{
Synthesis, characterization, anti-ulcer action and molecular docking evaluation of novel benzimidazole-pyrazole hybrids
}

\author{
Abida Noor ${ }^{1}$, Neelum Gul Qazi ${ }^{2}$, Humaira Nadeem ${ }^{*}$, Arif-ullah Khan², Rehan Zafar Paracha ${ }^{3}$, Fawad Ali \\ and Adil Saeed ${ }^{1}$
}

\begin{abstract}
A series of six novel benzimidazole-pyrazole hybrid molecules was synthesized and characterized using elemental analysis (CHN) and spectroscopic methods ('HNMR, FT-IR). All the synthesized compounds were evaluated for their in vivo anti ulcerogenic activity using Albino rats (weighing 180-220 g). The interactions between the compounds and active site residues of $\mathrm{H}^{+} / \mathrm{K}^{+}$ATPase were investigated by molecular docking studies using autodock vina 4.0. $\mathrm{SCH} 28080$ was used to validate the docking results. Also the drug likeliness of these compounds was predicted using Molinspiration server in light of Lipinski's rule of five. All the six synthesized compounds exhibited higher anti-ulcer activity as compared to omeprazole. These novel hybrid compounds showed comparable anti-ulcer potential of $72-83 \%$ at dose level of $500 \mathrm{\mu g} / \mathrm{kg}$, whereas omeprazole showed $83 \%$ anti-ulcer activity at dose level of $30 \mathrm{mg} / \mathrm{kg}$. The results clearly indicate that these novel benzimidazole-pyrazole hybrids can present a new class of potential anti ulcer agents and can serve as new anti-ulcer drugs after further investigation.
\end{abstract}

Keywords: Benzimidazole-pyrazole, Anti-ulcer, $\mathrm{H}^{+} / \mathrm{K}^{+}$ATPase, Omeprazole, Autodock vina, Molinspiration

\section{Background}

Peptic ulcer disease is one of the ailments that influence numerous people around the globe particularly in the developing world [1]. About $10 \%$ of the world population is affected. As a consequence of peptic ulcer about 15,000 deaths occurs annually [2]. Certain aggressive and protective factors affect the acid release in gastrointestinal tract. Any imbalance in these factors may disrupt the mucosal protection and expose gastrointestinal lining to gastric acid leading to the lesions called ulcers [3]. Various medications including proton pump inhibitors and $\mathrm{H}_{2}$ receptor antagonist are available for the treatment of gastric ulcers, however clinical assessment of these medications have demonstrated side effects, incidence of relapses and drug interactions [4] thus, there is need

\footnotetext{
*Correspondence: humaira.nadeem@riphah.edu.pk

${ }^{1}$ Department of Pharmaceutical Chemistry, Riphah Institute of Pharmaceutical Sciences, Riphah International University, Islamabad, Pakistan

Full list of author information is available at the end of the article
}

to identify more effective and safe anti-ulcer agent. The rapidly growing research in this field suggests that, with remedial and nutritional advances, gastric ulcer may become preventable within the next decade. This can be done by strengthening the defense mechanisms of the gastric mucosa and, in parallel, limiting the factors resulting in gastric ulceration. The present study focuses on the development of drugs which can reduce these damaging factors, thus preventing the ulcer formation.

With the discovery of $\mathrm{H}^{+} / \mathrm{K}^{+}$ATPase as the primary gastric proton pump, inhibition of $\mathrm{H}^{+} / \mathrm{K}^{+}$ATPase as a means of controlling gastric $\mathrm{pH}$ has gained extensive interest in recent years with the discovery of benzimidazole sulfoxide class of anti-secretory agents. Timoprazole, as one of the first well-defined inhibitor of gastric proton pump [5] which was followed by more potent picoprazole and omeprazole [6]. Synthetic benzimidazole derivatives play a major role in various pathological complications due to their high biological activity and wide range of clinical uses. The benzimidazole ring system is present in numerous anti-inflammatory [7] anti-viral [8] anti-cancer 
[9] and anti-microbial agents [10]. The anti-ulcer activity of sulfinyl containing benzimidazole is proved [11]. Synthetic substituted 2-mercaptobenzimidazole derivatives have been previously reported as anti-ulcer [12].

The special structural features and antiulcer potential of mercaptobenzimidazole derivatives encouraged us to synthesize some pyrazole and mercaptobenzimidazole hybrids and screen them for their anti-ulcer activity. Docking studies of the synthesized compounds were carried out against $\mathrm{H}^{+} / \mathrm{K}^{+}$ATPase.

\section{Materials and methods Chemistry}

All chemicals were purchased from common commercial suppliers and used without further purification. Melting points $(\mathrm{mp})$ were determined on a Gallenkamp melting point apparatus and were uncorrected. The IR spectra were recorded on Thermo scientific NICOLET IS10 spectrophotometer. All ${ }^{1} \mathrm{H}$ NMR and ${ }^{13} \mathrm{C}$ NMR spectra were recorded on Bruker AM-300 spectrophotometer at 300 and $100 \mathrm{MHz}$ respectively, in DMSO as a solvent and TMS as an internal standard at Quaid-e-Azam University, Islamabad.

\section{General procedure for the preparation of compounds Synthesis of 2-mercapto benzimidazole (1)}

Compound 1 was prepared according to the reported procedure [13].

\section{Synthesis of ethyl 2-(benzimidazolylthio) acetate (2)}

An equimolar solution of 2-mercapto benzimidazole (1) $(1.50 \mathrm{~g}, 0.01 \mathrm{~mol})$ and ethylchloroacetate $(1.22 \mathrm{~mL}$, $0.01 \mathrm{~mol})$ in dry acetone $(4 \mathrm{~mL})$ in presence of anhydrous $\mathrm{K}_{2} \mathrm{CO}_{3}(1 \mathrm{~g})$ was refluxed on a water bath for $6 \mathrm{~h}$. The solvent was removed by vacuum distillation and the residue was recrystallized from chloroform to furnish compound 2 (1.055 g, 70\%). m. p.: $6064{ }^{\circ} \mathrm{C}$; IR $\left(\mathrm{cm}^{-1}\right) 3042\left(\mathrm{SP}^{2} \mathrm{CH}\right)$, $1722(\mathrm{C}=\mathrm{O}$ of ester $), 1684(\mathrm{C}=\mathrm{N}), 1320$ and $1234(\mathrm{C}-\mathrm{O}-$ C), ${ }^{1} \mathrm{H}-\mathrm{NMR}\left(300 \mathrm{MHz}, \mathrm{DMSO}-d_{6}\right) \mathrm{ppm}: 1.40(\mathrm{t}, 3 \mathrm{H}$, $\left.\mathrm{J}=7 \mathrm{~Hz}, \mathrm{CH}_{3}\right), 4.08\left(\mathrm{q}, 2 \mathrm{H}, \mathrm{J}=6.75 \mathrm{~Hz}, \mathrm{CH}_{2}\right), 4.68(\mathrm{~s}$, 2H, S- $\left.\mathrm{CH}_{2}\right), 6.93-7.78(\mathrm{~m}, 4 \mathrm{H}, \mathrm{Ar}-\mathrm{H}), 11.2(\mathrm{~s}, 1 \mathrm{H}, \mathrm{NH})$. Anal. calcd. For $\mathrm{C}_{11} \mathrm{H}_{12} \mathrm{~N}_{2} \mathrm{O}_{2} \mathrm{~S}: \mathrm{C}, 55.93 ; \mathrm{H}, 5.10 ; \mathrm{N}, 11.86$. Found: C, 55.83; H, 5.04; N, 11.75 .

\section{Synthesis of [(2-benzimidazolylthio)-acetyl]-hydrazine (3)}

Compound 2 (2.36 g, $0.01 \mathrm{~mol})$ and hydrazine hydrate $(0.9 \mathrm{~mL}, 0.02 \mathrm{~mol})$ in ethanol $(20 \mathrm{~mL})$ were refluxed for about $5 \mathrm{~h}$ on oil bath. After cooling, the resulting solid was filtered, dried and recrystallized from ethanol to obtain compound 3 (1.77 g, 75\%). m. p.: $190-193{ }^{\circ} \mathrm{C}$; IR $\left(\mathrm{cm}^{-1}\right): 3311,3369\left(\mathrm{NHNH}_{2}\right), 1680(\mathrm{C}=\mathrm{O}) ;{ }^{1} \mathrm{H}-\mathrm{NMR}$ (300 MHz, DMSO- $d_{6}$ ) ppm: 4.02 (s, 2H, NH2), 4.45 (s, $\left.2 \mathrm{H}, \mathrm{S}-\mathrm{CH}_{2}\right), 7.05-7.95(\mathrm{~m}, 4 \mathrm{H}, \mathrm{Ar}-\mathrm{H}), 10.55$ (s, 1H, NH).
Anal. calcd. for $\mathrm{C}_{9} \mathrm{H}_{10} \mathrm{~N}_{4} \mathrm{OS}$ : C, 48.64; $\mathrm{H}, 4.80 ; \mathrm{N}, 25.22$. Found: C, 47.99; H, 4.69; N, 25.20.

\section{General procedure for the synthesis of benzimidazole-pyrazole hybrids}

Equimolar quantities of compound $3(0.5 \mathrm{~g}, 0.001 \mathrm{~mol})$ and respective chalcones $(0.001 \mathrm{~mol})$ were dissolved in ethanol $(50 \mathrm{~mL})$ containing $2-3 \mathrm{~mL}$ of glacial acetic acid. A few drops of hydrochloric acid were added as catalyst and the reaction mixture was refluxed for 16-17 h until the completion of reaction. After cooling, the resulting solution was added to ice cold water and resultant precipitates were collected by filtration.

2-(1H-benzimidazol-2-ylsulfanyl)-1-[5-(2-hydroxyphen yl)-3-phenyl-1H-pyrazol-1-yllethanone (5a) Yield 65\%, m. p. $190{ }^{\circ} \mathrm{C}$, IR $\left(\mathrm{cm}^{-1}\right) .3340(\mathrm{OH}), 1697(\mathrm{C}=\mathrm{O}), 1537$ $(\mathrm{C}=\mathrm{C}), 1617(\mathrm{C}=\mathrm{N}),{ }^{1} \mathrm{HNMR}\left(300 \mathrm{MHz}, \mathrm{DMSO}-d_{6}\right)$ ppm: $11.12(\mathrm{~s}, 1 \mathrm{H}, \mathrm{OH}), 9.02(\mathrm{~s}, 1 \mathrm{H}, \mathrm{NH}), 7.39-8.28(\mathrm{~m}$, $13 \mathrm{H}, \mathrm{Ar}-\mathrm{H}), 6.97$ (pyrazole $\mathrm{H}), 3.34\left(\mathrm{~s}, 2 \mathrm{H}, \mathrm{S}-\mathrm{CH}_{2}\right) \cdot{ }^{13} \mathrm{C}$ NMR $\left(100 \mathrm{MHz}, \mathrm{DMSO}-d_{6}\right)$ ppm: $157.55,153.00,149.35$, $149.35,145.89,142.35,139.74,133.35,131.85,128.92$, $128.70,128.70,125.76,125.45,125.45,122.53,122.45$, $121.82,119.87,118.01,115.45,107.23,107.18,32.10$. Anal. calcd. for $\mathrm{C}_{24} \mathrm{H}_{18} \mathrm{~N}_{4} \mathrm{O}_{2} \mathrm{~S}: \mathrm{C}, 67.60 ; \mathrm{H}, 4.22 ; \mathrm{N}, 13.14$. Found: C, 67.54; H, 4.20; N, 13.10 .

2-(1H-benzimidazol-2-ylsulfanyl)-1-[3,5-bis(2-hydro xyphenyl)-1H-pyrazol-1-yl]ethanone (5b) Yield 67\%, m. p. $185{ }^{\circ} \mathrm{C}$, IR $\left(\mathrm{cm}^{-1}\right) .2738(\mathrm{OH}), 1698(\mathrm{C}=\mathrm{O}), 1642$ $(\mathrm{C}=\mathrm{N}), 1540(\mathrm{C}=\mathrm{C}),{ }^{1} \mathrm{HNMR}\left(300 \mathrm{MHz}, \mathrm{DMSO}-d_{6}\right)$ ppm: 11.12 (s, 1H, OH), $9.00(\mathrm{~s}, 1 \mathrm{H}, \mathrm{NH}), 6.95-8.29(\mathrm{~m}$, $12 \mathrm{H}, \mathrm{Ar}-\mathrm{H}), 7.76$ (pyrazol H), $3.35\left(\mathrm{~s}, 2 \mathrm{H}, \mathrm{S}-\mathrm{CH}_{2}\right) .{ }^{13} \mathrm{C}$ NMR (100 MHz, DMSO- $d_{6}$ ) ppm: 157.45, 156.67, 153.00, $149.30,147.35,145.89,142.35,139.74,131.85,131.85$, $128.09,125.76,122.53,122.45,121.82,120.51,119.87$, $118.68,118.01,117.19,115.45,107.23,107.18,32.61$. Anal. calcd. for $\mathrm{C}_{24} \mathrm{H}_{18} \mathrm{~N}_{4} \mathrm{O}_{3} \mathrm{~S}: \mathrm{C}, 65.15 ; \mathrm{H}, 4.07 ; \mathrm{N}, 12.66$. Found: C, 65.13; H, 4.03; N, 12.62 .

2-(1H-benzimidazol-2-ylsulfanyl)-1-[5-(2-hydroxyphe nyl)-3-(3-hydroxy-4-methoxyphenyl) -1H-pyrazol-1-yl] ethanone (5c) Yield 59\%, m. p. $195{ }^{\circ} \mathrm{C}$, IR $\left(\mathrm{cm}^{-1}\right): 3121$ $(\mathrm{OH}), 1695(\mathrm{C}=\mathrm{O}), 1632(\mathrm{C}=\mathrm{N}), 1535(\mathrm{C}=\mathrm{C}),{ }^{1} \mathrm{HNMR}$ (300 MHz, DMSO- $d_{6}$ ) ppm: $14.18(\mathrm{~s}, 1 \mathrm{H}, \mathrm{OH}), 7.33-8.29$ $(\mathrm{m}, 11 \mathrm{H}, \mathrm{Ar}-\mathrm{H}), 7.56($ pyrazol $\mathrm{H}), 4.01\left(\mathrm{~s}, 3 \mathrm{H}, \mathrm{OCH}_{3}\right), 3.33$ (s, 2H, S- $\left.\mathrm{CH}_{2}\right) .{ }^{13} \mathrm{C}$ NMR (100 MHz, DMSO-d $)$ ppm; $158.43,156.67,149.35,148.16,147.35,145.89,145.85$, $142.35,139.74,131.85,131.85,129.05,128.09,122.53$, $122.45,120.51,119.87,118.68,117.19,112.24,111.02$, 107.23, 107.18, 56.15, 32.73. Anal. calcd. for $\mathrm{C}_{25} \mathrm{H}_{20} \mathrm{~N}_{4} \mathrm{O}_{4} \mathrm{~S}$ : C, 63.55; H, 4.23; N, 11.86. Found: C, 63.51; H, 4.22; N, 11.85 . 
2-(1H-benzimidazol-2-ylsulfanyl)-1-[5-(4-hydroxypheny aminol)-3-(2-hydroxyphenyl)-1H-pyrazol-1-yllethanone (5d) Yield 61\%, m. p. $200^{\circ} \mathrm{C}$, IR $\left(\mathrm{cm}^{-1}\right) 0.3319(\mathrm{OH}), 1681$ $(\mathrm{C}=\mathrm{O}), 1616(\mathrm{C}=\mathrm{N}), 1485(\mathrm{C}=\mathrm{C}),{ }^{1} \mathrm{HNMR}(300 \mathrm{MHz}$, DMSO- $\left.d_{6}\right)$ ppm: $11.13(\mathrm{~s}, 1 \mathrm{H}, \mathrm{OH}), 9.01(\mathrm{~s}, 1 \mathrm{H}, \mathrm{NH}), 6.95-$ $7.71(\mathrm{~m}, 12 \mathrm{H}, \mathrm{Ar}-\mathrm{H}), 6.96$ (pyrazol H), 3.34 (s, $\left.2 \mathrm{H}, \mathrm{S}-\mathrm{CH}_{2}\right)$. ${ }^{13} \mathrm{C}$ NMR (100 MHz, DMSO- $d_{6}$ ) ppm: 156.29, 154.12, $153.00,149.35, \quad 149.32, \quad 145.89,142.35,139.74, \quad 138.75$, $131.85,125.76,122.53,122.45,121.82,119.99,119.99$, $119.87,118.01,115.45,115.40,115.40,107.23,94.57,32.10$. Anal. calcd. for $\mathrm{C}_{24} \mathrm{H}_{19} \mathrm{~N}_{5} \mathrm{O}_{3} \mathrm{~S}: \mathrm{C}, 63.01 ; \mathrm{H}, 4.15 ; \mathrm{N}, 15.31$. Found: C, 63.02; H, 4.12; N, 15.29.

2-(1H-benzimidazol-2-ylsulfanyl)-1-(3,5-diphenyl-1H-pyrazol-1-yl)ethanone (5e) Yield 58\%, m. p. $170{ }^{\circ} \mathrm{C}$, IR $\left(\mathrm{cm}^{-1}\right)$ : $3056(\mathrm{NH}), 3217(\mathrm{OH}), 1683(\mathrm{C}=\mathrm{O})$, $1545(\mathrm{C}=\mathrm{N}), 1446(\mathrm{C}=\mathrm{C}),{ }^{1} \mathrm{HNMR}\left(300 \mathrm{MHz}, \mathrm{DMSO}-d_{6}\right)$ ppm: 11.12 (s, 1H, OH), $9.03(\mathrm{~s}, 1 \mathrm{H}, \mathrm{NH}), 6.51-7.12(\mathrm{~m}$, $14 \mathrm{H}, \mathrm{Ar}-\mathrm{H}), 6.78$ (pyrazol H), $3.32\left(\mathrm{~s}, 2 \mathrm{H}, \mathrm{S}-\mathrm{CH}_{2}\right) \cdot{ }^{13} \mathrm{C}$ NMR (100 MHz, DMSO- $d_{6}$ ) ppm: 157.55, 149.35, 149.35, $145.89,142.35,139.74,133.35,130.65,128.92,128.92$, $128.70,128.70,128.66,128.66,128.35,128.35,125.45$, $125.45,122.53,122.45,119.87,107.23,107.18,32.10$. Anal. calcd. for $\mathrm{C}_{24} \mathrm{H}_{18} \mathrm{~N}_{4} \mathrm{OS}$ : C, 70.24; H, 4.39; N, 13.65. Found: C, 70.21; H, 4.36; N, 13.62 .

2-(1H-benzimidazol-2-ylsulfanyl)-1-[5-(3-hydroxy-4-methoxyphenyl)-3-phenyl-1H-pyrazol-1-yl] ethanone (5f) Yield 59\%, m. p. $195^{\circ} \mathrm{C}$, IR $\left(\mathrm{cm}^{-1}\right): 3121$ $(\mathrm{OH}), 1695(\mathrm{C}=\mathrm{O}), 1632(\mathrm{C}=\mathrm{N}), 1535(\mathrm{C}=\mathrm{C}),{ }^{1} \mathrm{HNMR}$ (300 MHz, DMSO- $d_{6}$ ) ppm: 14.01 (s, $\left.1 \mathrm{H}, \mathrm{OH}\right), 7.23-8.09$ $(\mathrm{m}, 13 \mathrm{H}, \mathrm{Ar}-\mathrm{H}), 7.06$ (pyrazol H), $4.01\left(\mathrm{~s}, 3 \mathrm{H}, \mathrm{OCH}_{3}\right)$, 3.36 (s, $\left.2 \mathrm{H}, \mathrm{S}-\mathrm{CH}_{2}-\mathrm{CO}\right) .{ }^{13} \mathrm{C}$ NMR $(100 \mathrm{MHz}$, DMSO$\left.d_{6}\right)$ ppm: 157.50, 149.35, 149.30, 148.16, 145.89, 145.85, $142.35,139.74,133.30,131.85,129.05,128.92,128.70$, $128.70,125.40,125.40,122.53,122.45,119.87,112.24$, 111.02107.23, 107.18, 56.15, 32.10. Anal. calcd. for $\mathrm{C}_{25} \mathrm{H}_{20} \mathrm{~N}_{4} \mathrm{O}_{3} \mathrm{~S}: \mathrm{C}, 65.78 ; \mathrm{H}, 4.38 ; \mathrm{N}, 12.28$. Found: C, 65.75; $\mathrm{H}, 4.37 ; \mathrm{N}, 12.27$.

\section{Pharmacological assay Animals}

Albino rats (weighing 180-220 g) were housed at the animal house of the Riphah Institute of Pharmaceutical Sciences under controlled environment $\left(23-25^{\circ} \mathrm{C}\right)$. Animals were kept in plastic cages with sawdust (changed at every $48 \mathrm{~h}$ ) and were fasted for $24 \mathrm{~h}$ before starting the experiment. Animals were provided with tap water ad libitum and standard pellet diet. Experiments performed complied with rules of Institute of Laboratory Animal Resources, Commission on Life Sciences University, National Research Council (1996) and were approved by
Ethical Committee of Riphah Institute of Pharmaceutical Sciences, Riphah International University.

\section{Anti-ulcerogenic activity}

Albino rats (180-220 g) of either sex were divided into different groups $(n=5)$. Animals were fasted for $24 \mathrm{~h}$ before the study, but had free access to water. Animals in the control group received only normal saline $(10 \mathrm{~mL} /$ $\mathrm{kg}$ ). Compound $5 \mathrm{a}$ at doses of 100 and $500 \mu \mathrm{g} / \mathrm{kg}$, (p. o.) was given to the animals in the treatment group. Same procedure was repeated for Compund 5b, 5c, 5d, 5e and $5 \mathrm{f}$. Omeprazole $(30 \mathrm{mg} / \mathrm{kg})$ was used as a standard. The rats were sacrificed $1 \mathrm{~h}$ later and the stomach removed and observed for ulcers in the glandular region [3]. The surface area of each lesion was measured and scored by method with described by Tan et al. [14] with some modifications. The ulcer index for each rat was taken as the mean ulcer score (0: no ulcer; 1 : US $\leq 0.5 \mathrm{~mm}^{2}$; 2: $0.5<\mathrm{US} \leq 2.5 \mathrm{~mm}^{2} ; 3: 2.5 \mathrm{~mm}^{2}<\mathrm{US} \leq 5 \mathrm{~mm}^{2} ; 4$ : $5 \mathrm{~mm}^{2}<\mathrm{US} \leq 10 \mathrm{~mm}^{2} ; 5: 10 \mathrm{~mm}^{2}<\mathrm{US} \leq 15 \mathrm{~mm}^{2} ; 6$ : $15 \mathrm{~mm}^{2}<\mathrm{US} \leq 20 \mathrm{~mm}^{2} ; 7: 20 \mathrm{~mm}^{2}<\mathrm{US} \leq 25 \mathrm{~mm}^{2} ; 8$ : $25 \mathrm{~mm}^{2}<\mathrm{US} \leq 30 \mathrm{~mm}^{2} ; 9: 30 \mathrm{~mm}^{2}<\mathrm{US} \leq 35 \mathrm{~mm}^{2} ; 10$ : US $\left.>35 \mathrm{~mm}^{2}\right)$. The sum of the length $(\mathrm{mm})$ of all the lesions for each stomach was used as the ulcer index (UI). The percentage of inhibition (\% I) was calculated using the following formula:

$$
\% \mathrm{I}=(\mathrm{USc}-\mathrm{USt}) \times 100 / \mathrm{USc}
$$

where USc $=$ ulcer surface area of control and USt $=$ ulcer surface area of test animal [14].

\section{Docking studies}

\section{Drug likeliness evaluation}

Molinspiration server was used to predict number of rotatable bonds, hydrogen bond acceptors and hydrogen bond donors. These parameters help in evaluation of drug likeliness in light of Lipinski's rule of five [15]. According to this rule, for any compound to be a good drug candidate, it should have Molecular weight (MW) less than $500 \mathrm{Da}, \mathrm{H}$-bond donors (HBD) less than 5, $\mathrm{H}$-bond acceptors (HBA) less than 10, LogP value less or equal to 5 and total rotatable bonds less than 10 .

\section{Molecular docking}

The 3D structures of SCH28080, ligands (5a-5f), omeprazole, it's sulfenic acid and sulfenamide derivatives were drawn using DS Visualizer v16.1.0.15350 and saved in protein data bank (PDB) format. Polar hydrogens and charges were added by Autodock tools-1.5.6.

The three dimensional (3D) structure of Pig Gastric $\mathrm{H}^{+} / \mathrm{K}^{+}$ATPase (PDB code 2XZB) was retrieved from protein data bank [16]. The protein structure 
downloaded from protein data bank was used without any modification.

SCH28080 was used to validate the docking results because the PDB structure (2XZB) used in the docking analysis was obtained from enzyme crystallized along with it and its binding site was evaluated according to bound $\mathrm{SCH} 28080$ in the literature [16]. SCH28080 is a well known competitive inhibitor of gastric $\mathrm{H}^{+} / \mathrm{K}^{+}$ ATPase having comparable activity as of omeprazole [17]. Available literature indicate that omeprazole gets converted to its sulfenic acid and sulfenamide derivative in acidic environment and these forms bind to the Cys 813 sulfhydral group by making a covalent disulfide linkage $[18,19]$. Due to this reason sulfenic acid and sulfenamide derivatives of omeprazole were also docked along with synthesized compounds.

Molecular docking was carried out by help of Pyrx 0.8 and selecting Autodock vina as docking software [20]. Vina search space coordinates were set as $x=29.161$, $\mathrm{y}=34.533$ and $\mathrm{z}=-70.686$. Dimensions of search space were set as $\mathrm{x}=29.279, \mathrm{y}=20.040$ and $\mathrm{z}=27.678$. Exhaustiveness was set at 100 . All docked poses were saved in PDB format for further analysis on PyMOL Version 1.7.4.5 Edu and DS Visualizer v16.1.0.15350 [21].

\section{Acute toxicity test}

The test was performed using increasing doses $(10,30$ and $100 \mathrm{mg} / \mathrm{kg}$ ) of the test compounds, given orally in $10 \mathrm{~mL} / \mathrm{kg}$ volume to rats. The animals were allowed food ad libitum and kept under observation for mortality in $24 \mathrm{~h}[22]$.

\section{Statistical analysis}

Data expressed are mean \pm standard error of mean (SEM, $\mathrm{n}=$ number of experiment). The statistical parameter applied is one-way analysis of variance with post hoc Tukey test, $P<0.05$ noted as significantly different.

\section{Results and discussion Chemistry}

As shown in scheme, the benzimidazole-Pyrazole $5(\mathrm{a}-\mathrm{f})$ hybrids were prepared by three step synthesis starting from 2-mercaptobenzimidazole 1 . Treatment of compound 1 with ethyl chloroacetate in the presence of $\mathrm{KOH}$ gave the corresponding ethyl 2-(benzimidazolylthio) acetate 2, which was further condensed with hydrazine hydrate to afford the hydrazide 3 in $75 \%$ yield. The hydrazide was further reacted with six different chalcones $4 \mathbf{a}-\mathbf{f}$ in the presence of acetic acid and hydrochloric acid and respective pyrazole derivatives $5 \mathbf{a}-\mathbf{f}$ were obtained in $60-70 \%$ yield (Fig. 1). All the compounds were purified by recrystallization in suitable solvents. The structures of compounds $\mathbf{5 a}-\mathbf{f}$ were confirmed by
IR, NMR spectroscopic data and mass analysis. The IR spectra showed the carbonyl peak for amide and $\mathrm{OH}, \mathrm{NH}$ stretching vibrations. The ${ }^{1} \mathrm{H}$ NMR data of all the final compounds 5a-f showed a singlet at $\delta 6.95-7.76 \mathrm{ppm}$ which was characteristic of an aromatic proton of pyrazole ring. Methylene protons attached to sulfur atom were observed at $\delta 3.34 \mathrm{ppm}$, while all other aromatic protons resonated in the region $\delta 6.95-8.29 \mathrm{ppm}$. In compound $\mathbf{5 d}$ and $\mathbf{5 f}$, a singlet of methoxy protons resonated at $\delta 4.01 \mathrm{ppm}$. Singlet of $\mathrm{NH}$ and $\mathrm{OH}$ protons were observed downfield in all the compounds.

\section{Anti-ulcerogenic assay}

The anti-ulcer activity of all the benzimidazole-pyrazole hybrids $\mathbf{5 a}-\mathbf{f}$ was tested in vivo by ethanol-induced gastric ulcer model in rats. Rats received test compounds in two different doses; 100 and $500 \mu \mathrm{g} / \mathrm{kg}$ orally. Omeprazole $(30 \mathrm{mg} / \mathrm{kg})$ was used as a standard. The rats were sacrificed $1 \mathrm{~h}$ later and the stomach removed and observed for ulcers in the glandular region [3]. The surface area of each lesion was measured and scored by method [14]. All compounds (5a-f) exhibited anti-ulcer effect. Figure 2 show the gastric mucosa of rats. Compound $5 \mathrm{a}$ at 100 and $500 \mu \mathrm{g} / \mathrm{kg}$ caused 35.4 and $78.5 \%(P<0.001$ versus saline group) inhibition respectively, compound $5 \mathrm{~b}$ at 100 and $500 \mu \mathrm{g} / \mathrm{kg}$ caused 30.2 and $74.7 \%$ inhibition respectively $(P<0.001$ versus saline group), compound $5 \mathrm{c}$ exhibited 29.4 and $70.3 \%$ inhibition of ulcer formation at 100 and $500 \mu \mathrm{g} / \mathrm{kg}$ respectively $(P<0.001$ versus saline group), compound $5 \mathrm{~d}$ at 100 and $500 \mu \mathrm{g} / \mathrm{kg}$ showed 38.1 and $83.1 \%$ inhibition respectively $(P<0.001$ versus saline group), compound $5 e$ exhibited 36.2 and $79 \%$ inhibition at 100 and $500 \mu \mathrm{g} / \mathrm{kg}$ respectively $(P<0.001$ versus saline group), compound $5 \mathrm{f}$ at 100 and $500 \mu \mathrm{g} / \mathrm{kg}$ showed 24.8 and $72.1 \%$ inhibition respectively $(P<0.001$ versus saline group) and omeprazole (30 mg/kg) exhibited $83.1 \%$ inhibitory effect (Table 1). The results clearly indicated the greater anti-ulcer potential of our synthesized compounds as compared to omeprazole, the currently used anti-ulcer drug. All the compounds $5 \mathrm{a}-\mathrm{f}$ showed higher antiulcer activity at higher dose level of $500 \mu \mathrm{g} / \mathrm{kg}$. It was observed that substitution pattern of both the aromatic rings attached to pyrazole ring effect the anti-ulcer activity. The highest activity was shown by compound $5 \mathrm{~d}$ i.e. $83.1 \%$ at $500 \mu \mathrm{g} / \mathrm{kg}$ dose. All the compounds were docked against $\mathrm{H}^{+} / \mathrm{K}^{+}$ATPase to assess the binding affinities and compared with Omeprazole which is a known mercapto benzimidazole derivative and $\mathrm{H}^{+} / \mathrm{K}^{+}$ATPase inhibitor. As suggested by computational studies, all compounds bind with $\mathrm{H}^{+} / \mathrm{K}^{+}$ATPase having good binding affinities. $5 \mathrm{~d}$ has maximum binding affinity of $-9.8 \mathrm{kcal} / \mathrm{mole}$ due to maximum number of hydrogen bonding interactions with the target. Compound 5e and 5a also exhibited good 


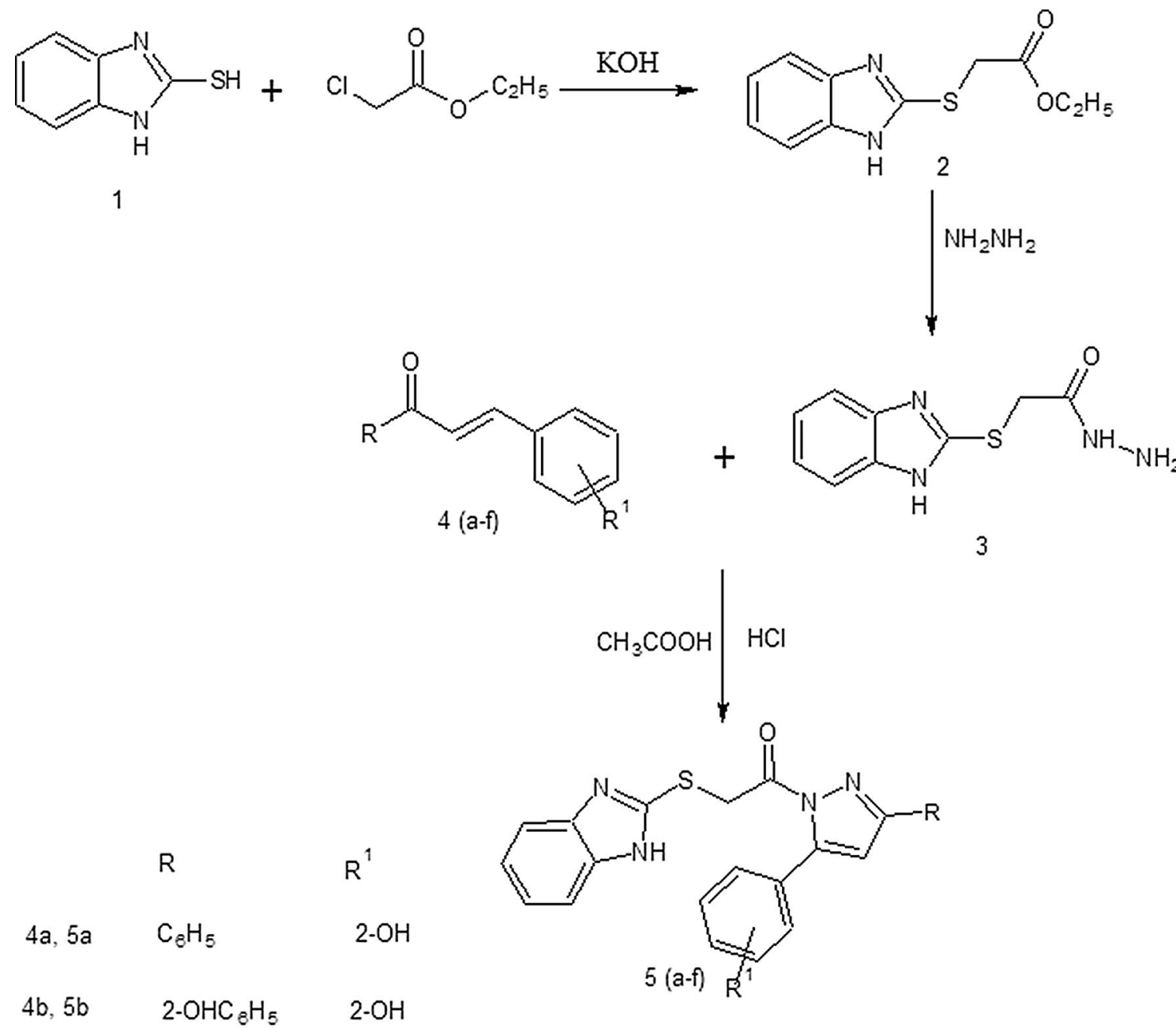

$4 \mathrm{c}, 5 \mathrm{C} \quad 2-\mathrm{OHC}_{2} \mathrm{H}_{5} \quad 3-\mathrm{OH}, 4-\mathrm{OCH}_{3}$

$4 d, 5 d \quad 4-\mathrm{OHC}_{8} \mathrm{H}_{5} \mathrm{NH} \quad 2-\mathrm{OH}$

$4 \mathrm{e}, 5 \mathrm{e} \quad \mathrm{C}_{8} \mathrm{H}_{5} \quad \mathrm{H}$

$4 f, 5 f \quad 3-\mathrm{OH}, 4-\mathrm{OCH}_{3} \quad \mathrm{H}$

Fig. 1 Synthesis of Mercatobenzimidazole-Pyrazole-hybrid derivatives

(See figure on next page.)

Fig. 2 Gross appearance of gastric mucosa in rats: a pre-treated with saline, $10 \mathrm{~mL} / \mathrm{kg}$ (ulcer control). Severe injuries are seen, as absolute ethanol $(1 \mathrm{~mL} / 100 \mathrm{~g})$ produced excessive visible hemorrhagic necrosis in gastric mucosa $\mathbf{b}$ and $\mathbf{c}$ pre-treated with compound $5 \mathrm{a}$ at doses of 100 and $500 \mu \mathrm{g} / \mathrm{kg}$, d and e pretreated with compound $5 \mathrm{~b}$ at doses of 100 and $500 \mu \mathrm{g} / \mathrm{kg}$, $\mathbf{f}$ and $\mathbf{g}$ pre-treated with compound $5 \mathrm{c}$ at doses of 100 and $500 \mu \mathrm{g} / \mathrm{kg}, \mathbf{h}$ and $\mathbf{i}$ pre-treated with compound $5 \mathrm{~d}$ at doses of 100 and $500 \mu \mathrm{g} / \mathrm{kg}, \mathbf{j}$ and $\mathbf{k}$ pre-treated with compound $5 \mathrm{e}$ at doses of 100 and $500 \mathrm{\mu g} / \mathrm{kg}$, I and $\mathbf{m}$ pre-treated with compound $5 \mathrm{f}$ at doses of 100 and $500 \mu \mathrm{g} / \mathrm{kg}$ and $\mathbf{n}$ pre-treated with omeprazole $30 \mathrm{mg} / \mathrm{kg}$. The injuries reduce with increase of compounds doses and omeprazole, compared to ulcer control 


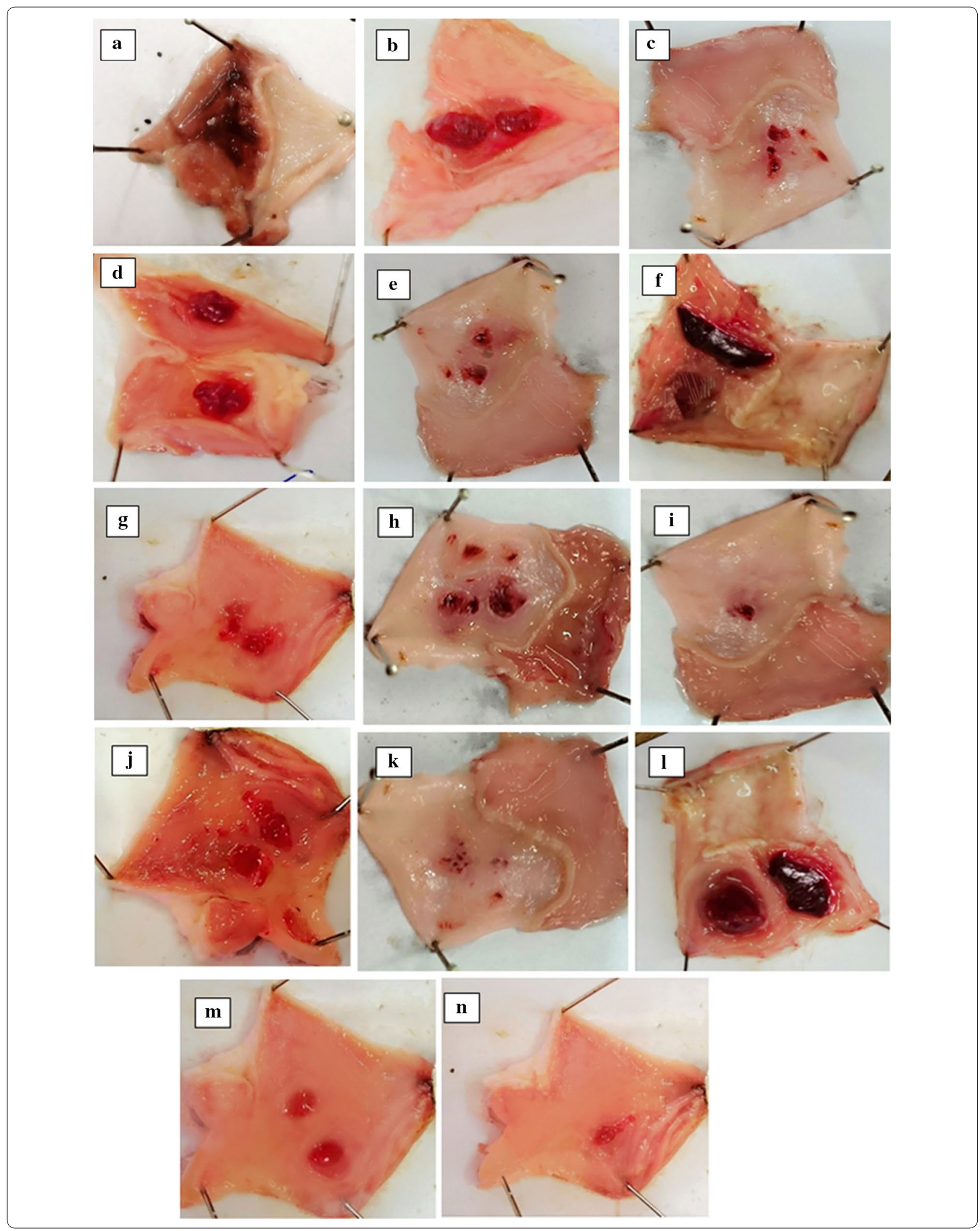


Table 1 Protective effect of compounds and omeprazole against ethanol-induced gastric ulcers in rats

\begin{tabular}{|c|c|c|}
\hline Treatment & Ulcer index & $\%$ Inhibition \\
\hline Saline $10 \mathrm{~mL} / \mathrm{kg}$ + Ethanol $(1 \mathrm{~mL} / 100 \mathrm{~g})$ & $4.99 \pm 0.007$ & - \\
\hline $\begin{array}{l}\text { Compund } 5 \mathrm{a}(100 \mu \mathrm{g} / \mathrm{kg})+\text { Ethanol } \\
(1 \mathrm{~mL} / 100 \mathrm{~g})\end{array}$ & $3.22 \pm 0.009^{* * *}$ & 35.4 \\
\hline $\begin{array}{l}\text { Compound } 5 \mathrm{a}(500 \mu \mathrm{g} / \mathrm{kg})+\text { Ethanol } \\
(1 \mathrm{~mL} / 100 \mathrm{~g})\end{array}$ & $1.07 \pm 0.008^{* * *}$ & 78.5 \\
\hline $\begin{array}{l}\text { Compund } 5 \mathrm{~b}(100 \mu \mathrm{g} / \mathrm{kg})+\text { Ethanol } \\
(1 \mathrm{~mL} / 100 \mathrm{~g})\end{array}$ & $3.48 \pm 0.008^{* * *}$ & 30.2 \\
\hline $\begin{array}{l}\text { Compound 5b }(500 \mu \mathrm{g} / \mathrm{kg})+\text { Ethanol } \\
(1 \mathrm{~mL} / 100 \mathrm{~g})\end{array}$ & $1.26 \pm 0.009^{* * *}$ & 74.7 \\
\hline $\begin{array}{l}\text { Compund 5c }(100 \mu \mathrm{g} / \mathrm{kg})+\text { Ethanol } \\
(1 \mathrm{~mL} / 100 \mathrm{~g})\end{array}$ & $3.52 \pm 0.009^{* * *}$ & 29.4 \\
\hline $\begin{array}{l}\text { Compound } 5 \mathrm{c}(500 \mu \mathrm{g} / \mathrm{kg})+\text { Ethanol } \\
(1 \mathrm{~mL} / 100 \mathrm{~g})\end{array}$ & $1.48 \pm 0.009^{* * *}$ & 70.3 \\
\hline $\begin{array}{l}\text { Compund } 5 \mathrm{~d}(100 \mu \mathrm{g} / \mathrm{kg})+\text { Ethanol } \\
(1 \mathrm{~mL} / 100 \mathrm{~g})\end{array}$ & $3.09 \pm 0.007^{* * *}$ & 38.1 \\
\hline $\begin{array}{l}\text { Compound } 5 \mathrm{~d}(500 \mu \mathrm{g} / \mathrm{kg})+\text { Ethanol } \\
(1 \mathrm{~mL} / 100 \mathrm{~g})\end{array}$ & $0.84 \pm 0.017^{* * *}$ & 83.1 \\
\hline $\begin{array}{l}\text { Compund } 5 \mathrm{e}(100 \mu \mathrm{gg} / \mathrm{kg})+\text { Ethanol } \\
(1 \mathrm{~mL} / 100 \mathrm{~g})\end{array}$ & $3.18 \pm 0.01^{* * *}$ & 36.2 \\
\hline $\begin{array}{l}\text { Compound 5e }(500 \mu \mathrm{gg} / \mathrm{kg})+\text { Ethanol } \\
(1 \mathrm{~mL} / 100 \mathrm{~g})\end{array}$ & $1.06 \pm 0.01^{* * *}$ & 79 \\
\hline $\begin{array}{l}\text { Compund } 5 \mathrm{f}(100 \mu \mathrm{g} / \mathrm{kg})+\text { Ethanol } \\
(1 \mathrm{~mL} / 100 \mathrm{~g})\end{array}$ & $3.75 \pm 0.016^{* * *}$ & 24.8 \\
\hline $\begin{array}{l}\text { Compound } 5 f(500 \mu \mathrm{g} / \mathrm{kg})+\text { Ethanol } \\
(1 \mathrm{~mL} / 100 \mathrm{~g})\end{array}$ & $1.39 \pm 0.02^{* * *}$ & 72.1 \\
\hline $\begin{array}{l}\text { Omeprazole }(30 \mathrm{mg} / \mathrm{kg})+\text { Ethanol } \\
(1 \mathrm{~mL} / 100 \mathrm{~g})\end{array}$ & $0.84 \pm 0.01^{* * *}$ & 83.1 \\
\hline
\end{tabular}

*** $P<0.001$ compared to control saline group, one-way analysis of variance with post hoc Tukey test, $\mathrm{n}=5$

binding affinities of -9.4 and $-9.5 \mathrm{kcal} / \mathrm{mole}$, whereas in case of compound $5 \mathrm{c}$ and $5 \mathrm{f}$ binding affinity is less which can be attributed to the presence of 3-OH group which leads to less binding affinity as compared to $4-\mathrm{OH}$, also the replacement of $4-\mathrm{OH}$ by $4-\mathrm{OCH} 3$ group in $5 \mathrm{a}$ and $5 \mathrm{f}$ resulted in disappearance of hydrogen bonding and hence decreased the binding energy. As evident from results the $\mathrm{OH}$ group of ring $\mathrm{A}$ is not involved in hydrogen bonding and therefore its absence in case of $5 \mathrm{a}$ increased the binding affinity, while the ortho hydroxyl group of ring $B$ increased binding affinity as it is involved in hydrogen bonding with the target.

Recently some new derivatives of mercapto benzimidazole have been reported for their strong inhibitory potential against $\mathrm{H}^{+} / \mathrm{K}^{+}$ATPase. These compounds include 2-[3-(2,3-dihydro-1Hpyrolo[1,2a]benzimidazolyl)sulfinyl]-5-methyl-1H benzimidazoles, 20379-4 [23] 5,7-dihydro-2\{[(4methoxy-3-methyl-2-pyridyl) methyl] sulfinyl $\}-5,5,7,7$-tetramethylindeno-[5,6d] imidazole-6- $(1 \mathrm{H})$-one (Ro185364), [24], 4-(N-allyl-Nmethylamino)-1-ethyl-8-[(5-fluoro-6-methoxy-2-benzimidazolyl) sulfinylmethyl]1-ethyl-1,2,3,4-tetrahydroquinoline [25] and 2-(1H-benzoimidazole-2-sulfinylmethyl)-4-dimethylaminopyrimidine-5-carboxylicacid ethyl ester [26]. Therefore, we decided to synthesize the target molecules and screen them for antiulcer activity. The proposed hypothesis was that our compounds (5a-f) being resembling with omeprazole and SCH28080 might have antiulcer potential through the inhibition of $\mathrm{H}^{+} / \mathrm{K}^{+}$ATPase. To check the hypothesis docking studies were carried out and very good binding energies of our compound with the target comparable with omeprazole and SCH28080 were obtained. This suggests that $\mathrm{H}^{+} / \mathrm{K}^{+}$ATPase inhibition is a possible mechanism of action of these compounds, but involvement of other mechanisms cannot be ignored. Hypothesis can be validated through in vitro studies, which is part of our future plans.

\section{In-silico drug likeliness assessment}

Drug-likeness or drugability of molecules was assessed based on Lipinski rule of five as suggested by Christopher A. Lipinski. According to Lipinski's 'rule-of-five' drugs should have a molecular weight of $\leq 500 \mathrm{Da}$, a $\log \mathrm{P} \leq 5$, hydrogen bond donor $\leq 5$ and hydrogen bond acceptor sites ( $\mathrm{N}$ and $\mathrm{O}$ atoms) $\leq 10$ that they have strong absorption.

Drug likeliness of our synthesized compounds is given in Table 2. It indicated that compounds $5 \mathrm{c}$ and $5 \mathrm{f}$ are fulfilling all the criteria of lipinski's rule of five. The Predicted values of miLogP for all compounds are around 5 . In general all the synthesized compounds have identical activity according to milogP predictions. Compound $5 \mathrm{~d}$ has maximum number of hydrogen bond acceptor and hydrogen bond donor properties and highest total polar surface area of 116.06. Topological polar surface area (TPSA) was calculated for all the compounds. It should be $\leq 1405 \mathrm{~b}$ of a molecule which correlates well with the passive molecular transport through membranes.

All the compounds have TPSA within the range. The drug-likeness data of our compounds suggested that these compounds can be used as drugs because all of the above mentioned descriptors for these molecules are within the range.

\section{Molecular docking analysis}

Docking scores of first three best docked posses are given in Table 3. Docking scores predict that all the synthesized compounds $(5 a-5 f)$ will show slight difference in activity with $5 \mathrm{~d}$ having highest activity and compounds $5 \mathrm{c}$ and $5 \mathrm{f}$ having lowest activity of all. These docking results are in accordance with the results of in vivo activity. 
Table 2 Druglikeliness

\begin{tabular}{|c|c|c|c|c|c|c|c|c|c|}
\hline S. no & Ligand & miLog $P$ & TPSA & $\begin{array}{l}\text { Molecular } \\
\text { weight }\end{array}$ & $\begin{array}{l}\text { No. of H-bond } \\
\text { acceptor }\end{array}$ & $\begin{array}{l}\text { No. of H-bond } \\
\text { donor }\end{array}$ & $\begin{array}{l}\text { No. of viola- } \\
\text { tions }\end{array}$ & $\begin{array}{l}\text { No. of rotatable } \\
\text { bonds }\end{array}$ & Volume \\
\hline 1 & $5 a$ & 5.38 & 83.81 & 426.50 & 6 & 2 & 1 & 5 & 366.23 \\
\hline 2 & $5 b$ & 5.11 & 104.04 & 442.50 & 7 & 3 & 1 & 5 & 374.25 \\
\hline 3 & $5 c$ & 4.72 & 113.27 & 472.53 & 8 & 3 & 0 & 6 & 399.80 \\
\hline 4 & $5 d$ & 5.34 & 116.06 & 457.51 & 8 & 4 & 1 & 6 & 386.65 \\
\hline 5 & $5 e$ & 5.64 & 63.58 & 410.50 & 5 & 1 & 1 & 5 & 358.21 \\
\hline 6 & $5 f$ & 4.98 & 93.04 & 456.53 & 7 & 2 & 0 & 6 & 391.78 \\
\hline 7 & Omeprazole & 2.41 & 77.11 & 345.42 & 6 & 1 & 0 & 5 & 302.81 \\
\hline
\end{tabular}

Docking scores of synthesized compounds is also better than SCH28080, omeprazole, its sulfenic acid derivative (SC) and sulfenamide derivative (SA) predicting that synthesized compounds will be more active. This is also observed in in vivo activity test as dose for omeprazole was very higher than the dose of compounds $(5 a-f)$ suggesting that these compounds are far more potent than omeprazole.

In post docking analysis it was observed that compound $5 \mathrm{~b}, 5 \mathrm{c}$, and $5 \mathrm{f}$ are binding to the active site in almost same pose, whereas, $5 \mathrm{a}, 5 \mathrm{~d}$, and $5 \mathrm{e}$ are binding to the active site in totally different pose. According to docking score poses of compounds $5 \mathrm{a}, 5 \mathrm{~d}$ and $5 \mathrm{e}$ are energetically better than the posses of compounds $5 b, 5 c$ and $5 \mathrm{f}$ as shown in Fig. 3.

SCH28080 covers the Cys 813 in the binding pocket. It can be observed that compound $5 \mathrm{~d}$ covers the Cys 813 in the binding pocket in the same way as $\mathrm{SCH} 28080$ as expressed in Fig. 4. In Fig. 5 all compounds (5a-f) are shown docked in the binding pocket depicting that all compounds are binding to the same site with little variation in binding pose.

All of the compounds (5a-f) are showing more interactions with the amino acid residues surrounding the active site as compared to other reference molecules. It can be seen in the Fig. 6(a) that SCh28080 has fewer interactions with active site as compared to synthesized compounds $(5 a-f)$. Highest number of interactions is predicted in case of compound $5 \mathrm{~d}$ Fig. 7. Its two binding posses (mode 0 and 2) are given in Fig. 8a, b. Predicted interactions of omeprazole's sulfenic acid Fig. 9 and sulphenamide derivative are shown in Fig. 10a, b. Predicted interactions of omeprazole's sulfenamide derivate are also less than interactions of our compounds.
Table 3 Docking scores of first three best docked posses

\begin{tabular}{lllll}
\hline Ligand & $\begin{array}{l}\text { Binding affinity } \\
\text { (kcal/mol) }\end{array}$ & Mode & rmsd/ub & rmsd/lb \\
\hline 5a & -9.5 & 0 & 0 & 0 \\
5a & -9.5 & 1 & 7.294 & 2.981 \\
5a & -9.4 & 2 & 8.366 & 3.478 \\
5b & -9.4 & 0 & 0 & 0 \\
5b & -9.4 & 1 & 8.305 & 3.3 \\
5b & -9.4 & 2 & 7.025 & 3.268 \\
5c & -9.2 & 0 & 0 & 0 \\
5c & -9 & 1 & 6.477 & 3.593 \\
5c & -9 & 2 & 8.947 & 4.176 \\
5d & -9.8 & 0 & 0 & 0 \\
5d & -9.5 & 1 & 8.682 & 2.897 \\
5d & -9.5 & 2 & 6.742 & 3.731 \\
5e & -9.4 & 0 & 0 & 0 \\
5e & -9.4 & 1 & 8.741 & 4.258 \\
5e & -9.3 & 2 & 7.866 & 4.377 \\
5f & -9.2 & 0 & 0 & 0 \\
5f & -8.9 & 1 & 8.67 & 4.143 \\
5f & -8.8 & 2 & 6.344 & 3.617 \\
SCH28080 & -7.7 & 0 & 0 & 0 \\
SCH28080 & -7.7 & 1 & 1.855 & 1.386 \\
SCH28080 & -7.6 & 2 & 2.239 & 1.821 \\
Omeprazole & -7.7 & 0 & 0 & 0 \\
Omeprazole & -7.7 & 1 & 7.939 & 2.578 \\
Omeprazole & -7.6 & 2 & 2.229 & 1.456 \\
SA & -7.8 & 0 & 0 & 0 \\
SA & -7.2 & 1 & 3.942 & 2.388 \\
SA & -7 & 10.687 & 8.036 \\
SC & -7.7 & 0 & 7.333 & 0 \\
SC & -7.4 & 11.516 & 9.22 \\
SC & -7.3 & 091 \\
\hline
\end{tabular}



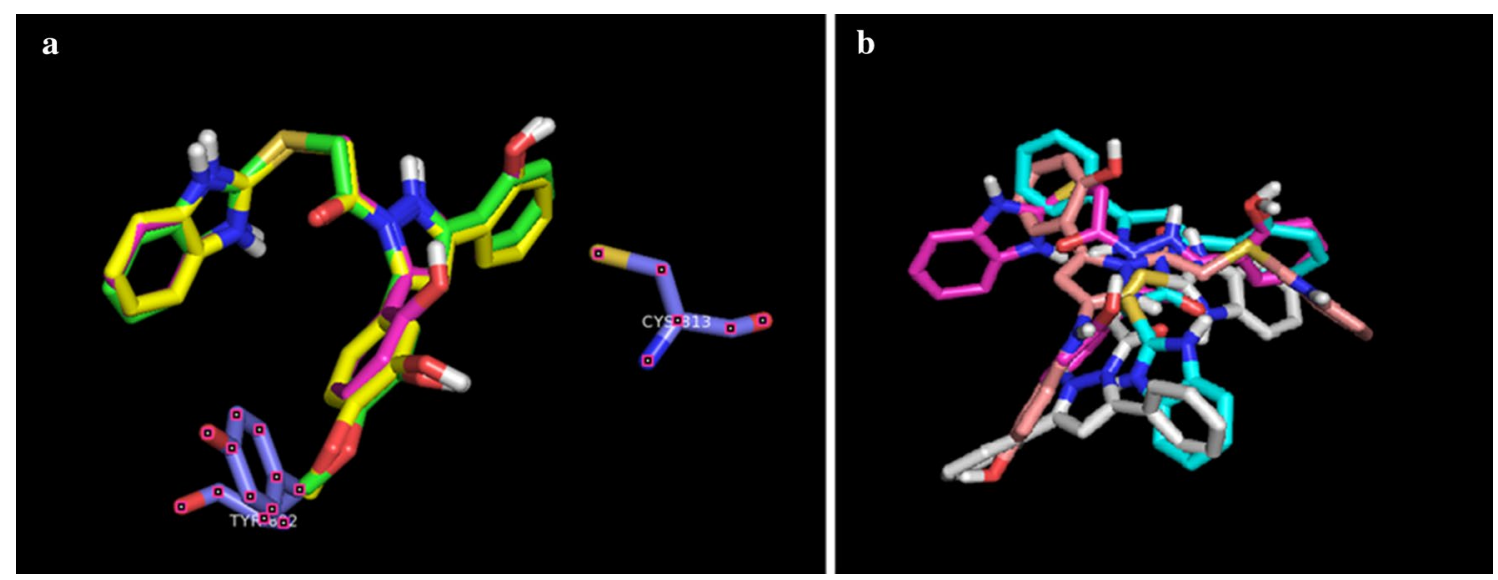

Fig. 3 bb, 5c and $5 f$ between Cys 813 and Tyr 802 of binding pocket (a) their binding poses are same and are overlapping with each other. 5a, 5b, $5 \mathrm{~d}$ and $5 \mathrm{e}$ have different binding poses $(\mathbf{b})$
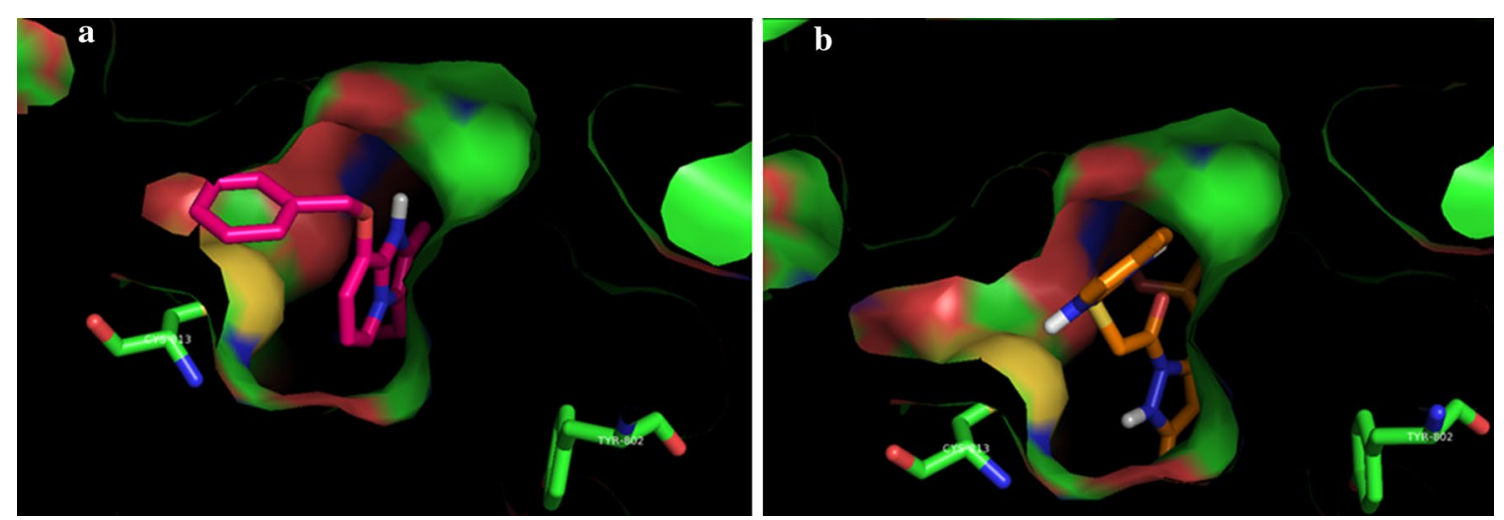

Fig. 4 SCH28080 covering the Cys813 in the active site (a). Compound 5d covering the Cys 813 in the active site (b)

\section{Acute toxicity}

The test compounds 5a, 5b, 5c, 5d and 5e did not causes any mortality up to dose of $100 \mathrm{mg} / \mathrm{kg}$. $5 \mathrm{f}$ was found lethal at the dose of $100 \mathrm{mg} / \mathrm{kg}$.

\section{Conclusions}

Six novel benzimidazole-pyrazole hybrids were synthesized and evaluated for their anti-ulcer activity. All the compounds exhibited potent anti-ulcer activity at lower 


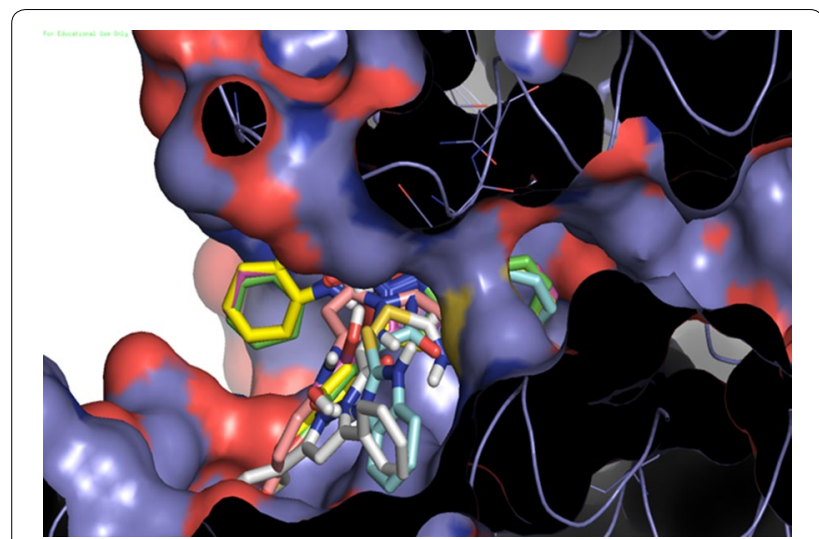

Fig. 5 Componds $5 a-5 f$ posses in binding pocket

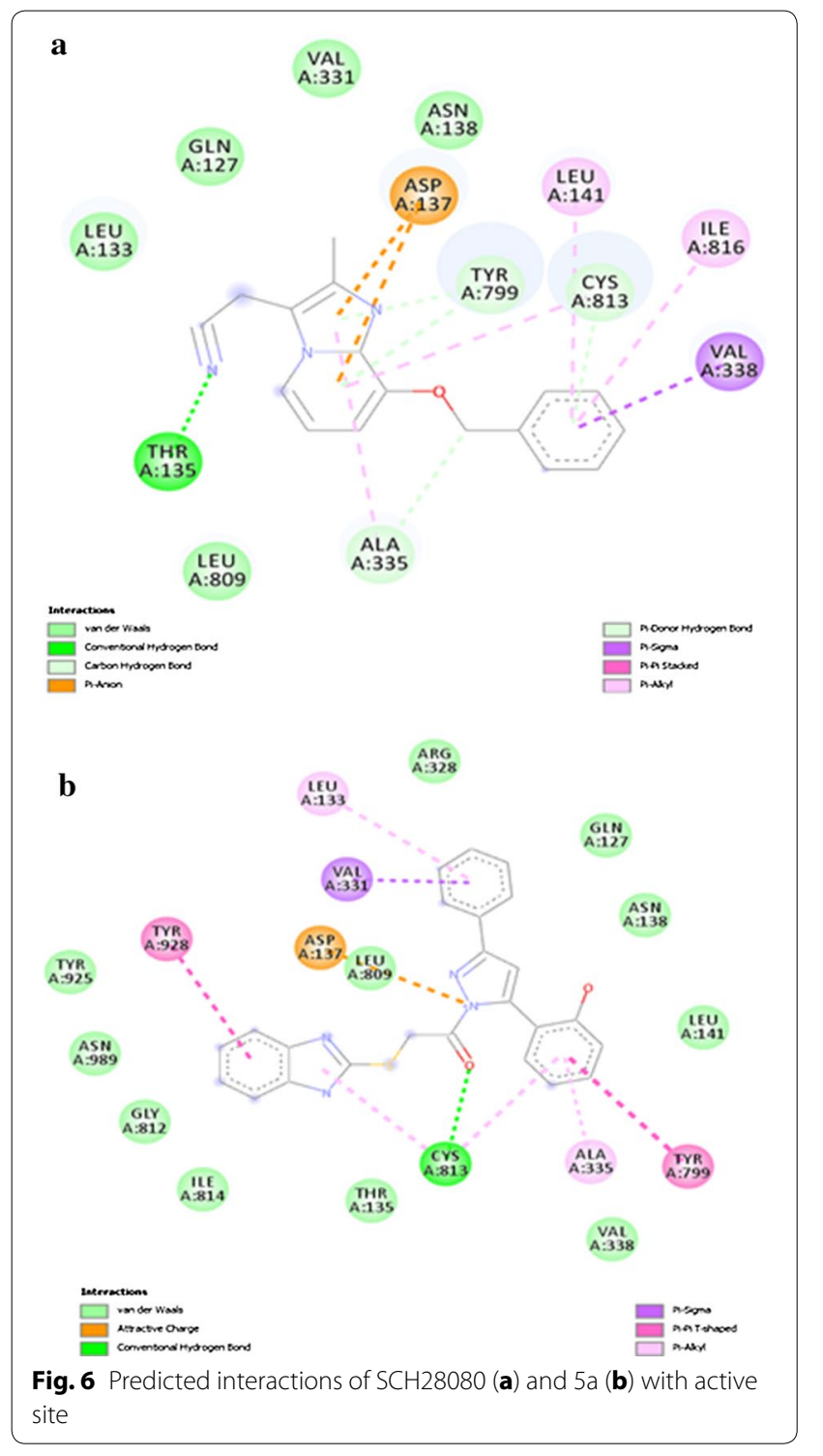

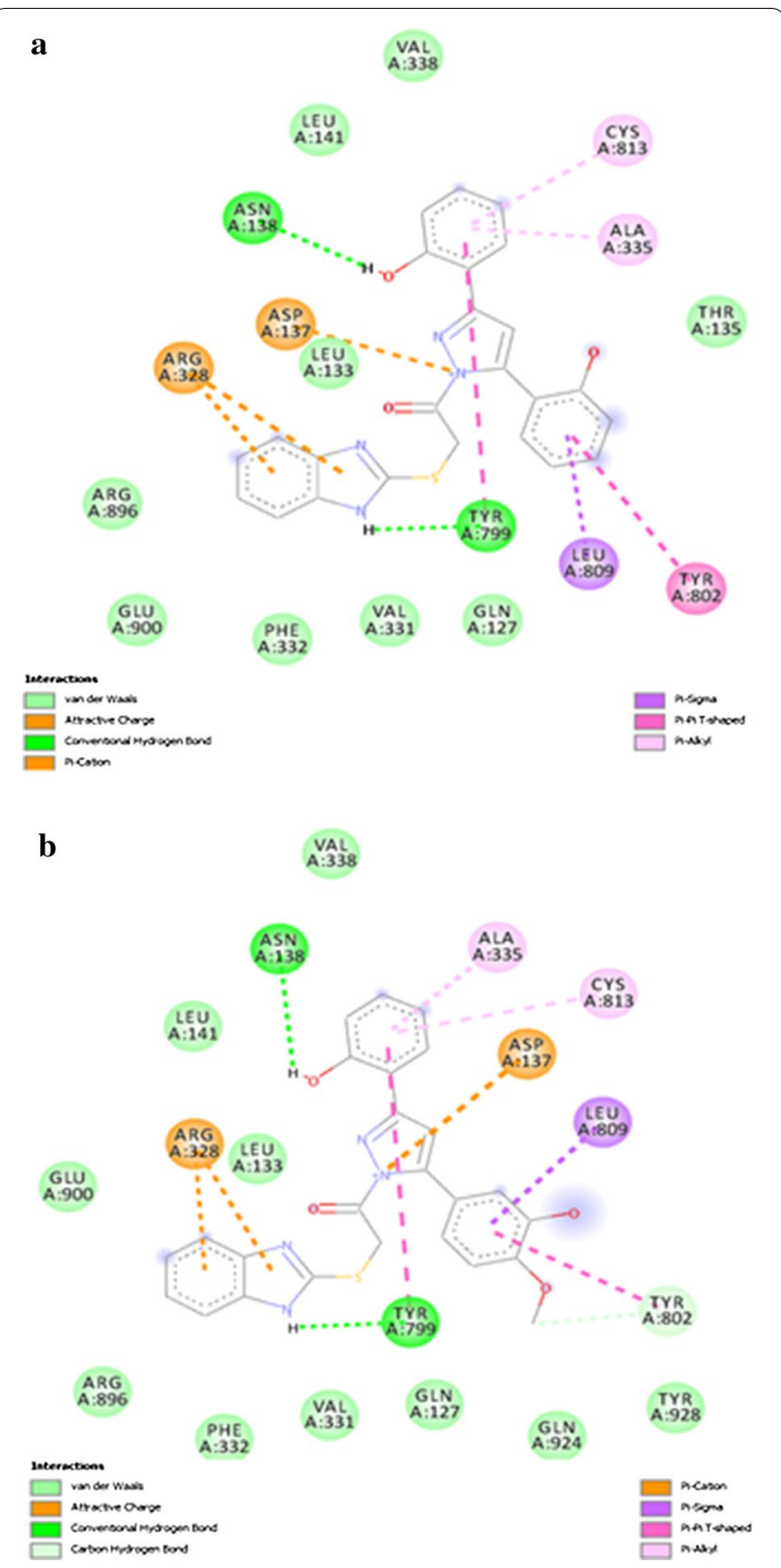

Fig. 7 Predicted interactions of $5 b(\mathbf{a})$ and $5 c(\mathbf{b})$ with active site

dose levels as compared to the standard, omeprazole. Further the molecular interaction of the these novel hybrids molecules with the target $\mathrm{H}^{+} / \mathrm{K}^{+}$ATPase were established through docking studies. It was found that our compounds showed higher binding affinities as compare to omeprazole. This suggest that compounds $(5 \mathrm{a}-\mathrm{f})$ might be acting through the same mechanism as omeprazole and other related compounds but involvement of other mechanism cannot be ignored. The study confirmed that these molecules can present a new class of lead molecules for drug discovery as $\mathrm{H}^{+} / \mathrm{K}^{+}$ATPase inhibitors. 

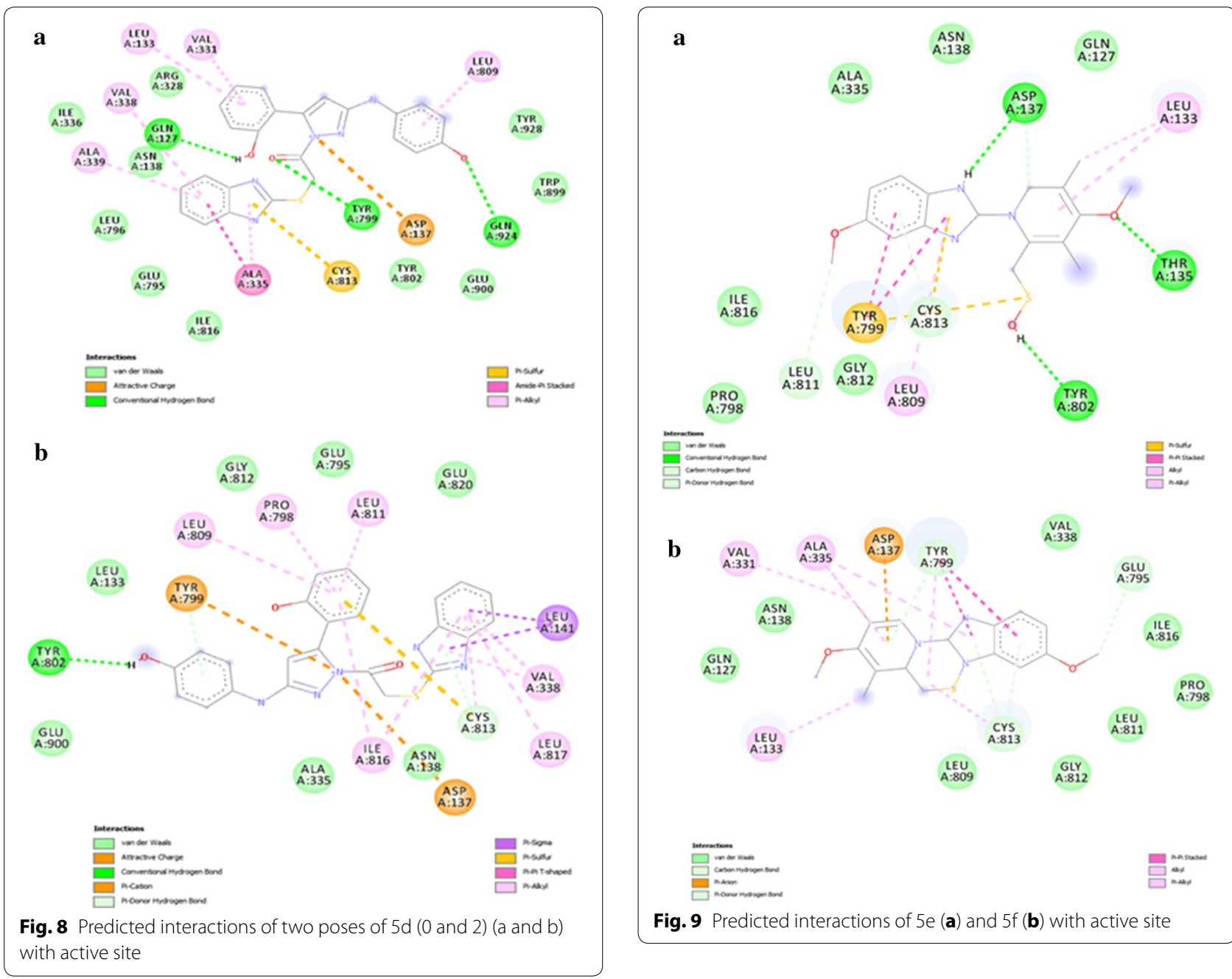

Fig. 9 Predicted interactions of $5 e(\mathbf{a})$ and $5 f(\mathbf{b})$ with active site 


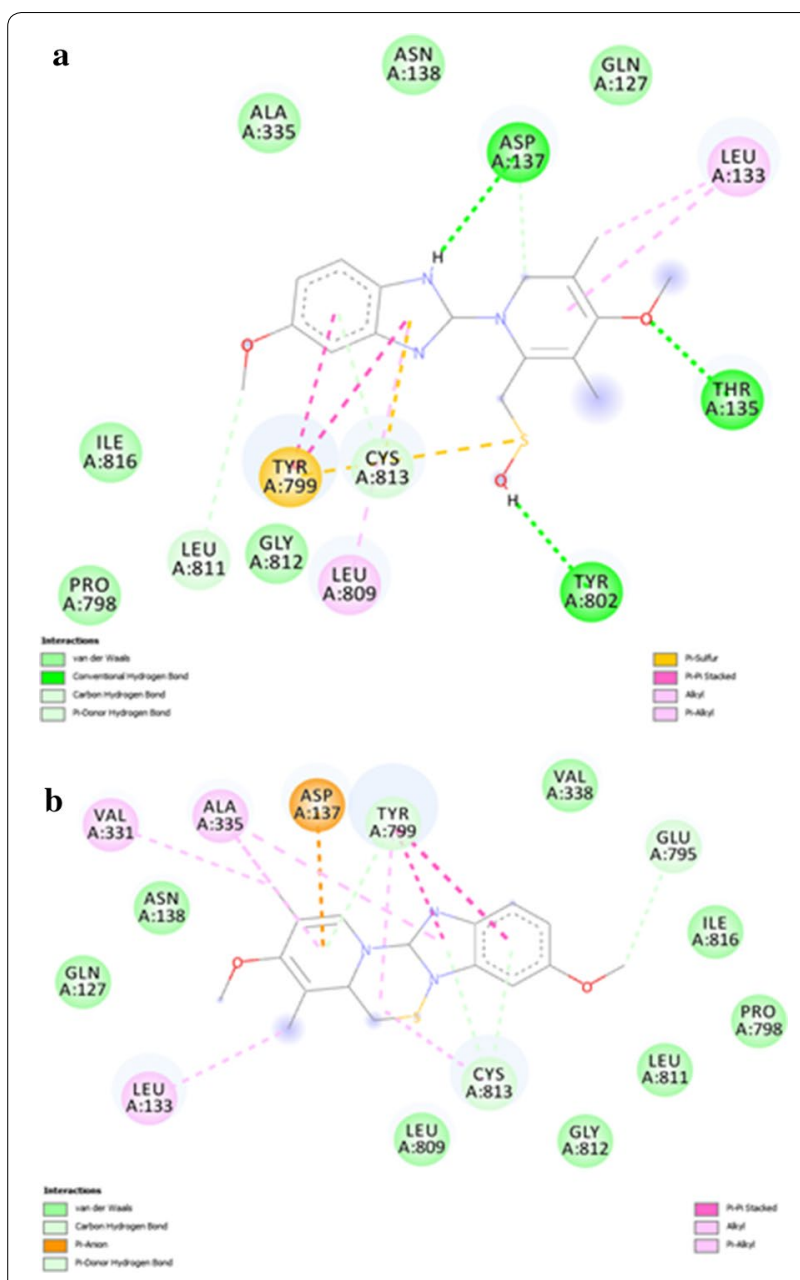

Fig. 10 Predicted interactions of omeprazole's sulfenic acid (a) and sulfenamide (b) derivatives with active site

\section{Authors' contributions}

HN and AK carried out study design, raised funds, supervised the work and refined the manuscript for publication. AN did experimental work in synthesis of compounds. FA and NGQ performed anti-ulcer activity, analysis of data and preparing draft manuscript. AS and RZP did in silico studies and corrected the manuscript for publication. All authors read and approved the final manuscript.

\section{Author details}

${ }^{1}$ Department of Pharmaceutical Chemistry, Riphah Institute of Pharmaceutical Sciences, Riphah International University, Islamabad, Pakistan. ${ }^{2}$ Department of Pharmacology, Riphah Institute of Pharmaceutical Sciences, Riphah International University, Islamabad, Pakistan. ${ }^{3}$ Research Center for Modeling and Simulation, National University of Science and Technology, Islamabad, Pakistan. ${ }^{4}$ Department of Pharmacy, Kohat University of Science and Technology, Kohat, Pakistan.

\section{Acknowledgements}

We are thankful to Islamic International Medical College Trust, Riphah International University for financial assistance.

\section{Competing interests}

The authors declare that they have no competing interests.

\section{Publisher's Note}

Springer Nature remains neutral with regard to jurisdictional claims in published maps and institutional affiliations.

Received: 18 February 2017 Accepted: 20 August 2017

Published online: 02 September 2017

\section{References}

1. Ezealisiji KM, ljeomah SC, Agbo MO (2014) Anti-ulcer activity of African walnut Tetracarpidium conophorum nuts against gastric ulcers in rats. Asian Pac J Trop Dis 4:998-1001

2. Sharma D, Bhatt SA (2014) Comprehensive review on ulcer healing potential of medicinal plants. Int J Pharm Pharm Sci 6:10

3. Hara N, Okabe S (1985) Effect of gefernate on acute lesions in rats. Folia Pharmacol Jap 85:443-448

4. Ateufack G, Domgnim Mokam EC, Mbiantcha M, Dongmo Feudjio RB, David N, Kamanyi A (2015) Gastroprotective and ulcer healing effects of Piptadeniastrum africanum on experimentally induced gastric ulcers in rats. BMC Complement Altern Med 15:214

5. Ruwart MJ, Nezamis JE, Rush BD, Lancaster C, Davis JP (1984) Timoprazole is a unique cytoprotective agent in the rat. Digestion 30:33-40

6. Lindberg P, Brandstrom A, Wallmark B, Mattsson H, Rikner L (1990) Omeprazole: the first proton pump inhibitor. Med Res Rev 10:1-54

7. Lazer ES, Farina PR, Oliver JT, Possanza GJ, Matteo MR (1987) Antiinflammatory benzimidazole derivative with inhibitory effects on neutrophil Function. J Med Chem 30:726-729

8. Freeman GA, Selleseth DW, Rideout JL, Harvey RJ (2000) Benzimidazole 2'-Isonucleosides: design, synthesis, and antiviral activity of 2-substituted-5, 6-Dichlorobenzimidazole 2'-Isonucleosides. Nucleos nucleot nucleic acids 19:155-174

9. Ibrahim ESA, Omar AMME, Mohsen ME, Khalil MA (1980) Novel potential anticancer agents derived from benzimidazole. J Pharm Sci 69:1348-1350

10. Muri EMF, Williamson JS (2004) Anti-Helicobacter pylori agents, an update. Mini Rev Med Chem 4:201-206

11. Ansari KF, Lal C (2009) Synthesis, physicochemical properties and antimicrobial activity of some new benzimidazole derivatives. Eur J Med Chem 44:4028-4033

12. Reddy MS, Anisetti RN, Prasad KD, Sannigrahi S, Reddy PA (2011) Synthesis, characterization and biological evaluation of some novel 2-substituted mercaptobenzimidazole derivatives. Pharm Chem J 44:642-645

13. Wang ML, Liu BL (2007) Synthesis of 2-mercaptobenzimidazole from the reaction of o-phenylene diamine and carbon disulfide in the presence of potassium hydroxide. J Chin Inst Chem Eng, 38:161-167

14. Tan PV, Nditafon GN, Yewah MP, Ayafor JF, Dimo T (1996) Eremomastax speciosa: effects of the leaves aqueous extract on ulcer formation and gastric secretion in rats. J Ethnopharmacol 73:139-142

15. Lipinski CA, Lombardo F, Dominy BW, Feeney PJ (2012) Experimental and computational approaches to estimate solubility and permeability in drug discovery and development settings. Adv Drug Deliv Rev 64:4-17

16. Abe K, Tani K, Fujiyoshi Y (2011) Conformational rearrangement of gastric $\mathrm{H}^{+} / \mathrm{K}^{+}$-ATPase induced by an acid suppressant. Nat Commun 2:155

17. Beil W, Hackbarth I, Sewing KF (1986) Mechanism of gastric antisecretory effect of SCH 28080. Br J Pharmacol 88:19-23

18. Lindberg $P$, Nordberg $P, A$ Alminger T, Braendstroem A, Wallmark B (1986) The mechanism of action of the antisecretory agent omeprazole. J Med Chem 29:1327-1329

19. Qaisi AM, Tutunji MF, Tutunji LF (2006) Acid decomposition of omeprazole in the absence of thiol: a differential pulse polarographic study at the static mercury drop electrode (SMDE). J Pharm Sci 95:384-391

20. Dallakyan S (2008) PyRx-python prescription v. 0.8. The Scripps Research Institute, La Jolla, p 2010

21. Delano W (2009) The PyMOL molecular graphics system. San Carlos, DeLano Scientific, p 2002

22. Sanmugapriya E, Venkataraman S (2006) Toxicological investigations on Strychnos potatorum seeds in experimental models. J Healt Sci 52:339-343 
23. Woo T, Chang M, Chung Y, Kim K, Sohn S, Kim S, Choi W (1998) Effects of YJA20379-4 on gastric secretion, Helicobacter pylori growth and various gastric and duodenal lesions in rats. Biol Pharm Bull 21:449-455

24. Sigirst-Nilson K, Krasso A, Muller RM, Fischli AE (1987) Ro18-5364, a potent new inhibitor of the gastric $\left(\mathrm{H}^{+} / \mathrm{K}^{+}\right)$-ATPase. Eur J Biochem 166:453-459

25. Uchida M, Chihiro M, Morita S, Yamashita H, Yamasaki K, Kanbe T, Yabuuchi Y, Nakagawa K (1990) Synthesis and antiulcer activity of 4-substituted 8-[(2-benzimidazolyl)sulfinylmethyl]1,2,3,4 -tetrahydroquinolines and related compounds. Chem Pharm Bull 38:1575-1586
26. Terashima K, Sato M, Ono M, Muraoka O (1995) Synthesis and mechanism of action of Ethyl2[(1 Hbenzimidazol-2-yl)sulfinylmethyl]-4-dimethylamino-5-pyridine carboxylate, a New $\mathrm{H}^{+} / \mathrm{K}^{+}$-ATPase inhibitor associated with mucosal protective activity, AFMC Medicinal Chemistry Symposium

\section{Submit your manuscript to a SpringerOpen ${ }^{\circ}$ journal and benefit from:}

- Convenient online submission

- Rigorous peer review

- Open access: articles freely available online

- High visibility within the field

- Retaining the copyright to your article

Submit your next manuscript at springeropen.com 